\title{
LIGNOCELLULOSE WASTE VALORIZATION BY AN ENZYMATIC COCKTAIL OF P. ERYNGII AND P. PULMONARIUS
}

\author{
MILICA GALIĆ, MIRJANA STAJIĆ and JASMINA ĆILERDŽIĆ \\ University of Belgrade, Faculty of Biology, Takovska 43, 11000 Belgrade, Serbia \\ 凶Corresponding author: J. Ćilerdžić, simonicj@bio.bg.ac.rs
}

Received September 17, 2021

\begin{abstract}
The present study aimed to characterize Pleurotus eryngii and P. pulmonarius ligninolytic enzymes and to determine their potential for polymer degradation in common agroforestry residues. The peak of laccase activity $\left(36052.33 \mathrm{U} \mathrm{L}^{-1}\right)$ was observed after $P$. pulmonarius cultivation on oak sawdust. The maximal Mn-dependent peroxidase activity was reached by $P$. eryngii $\left(2511.36 \mathrm{U} \mathrm{L}^{-1}\right)$, while the highest level of versatile peroxidase activity was noted in $P$. pulmonarius (3053.03 $\left.\mathrm{U} \mathrm{L}^{-1}\right)$, after fermentation of corn stalks. The highest level of lignin loss (46.28\%) was achieved after cultivation of $P$. pulmonarius on corn stalks, but the most selective degradation of lignocellulose polymers was observed after $P$. eryngii cultivation on wheat straw. The obtained results lead to the conclusion that the studied $P$. eryngii and $P$. pulmonarius strains are good producers of ligninolytic enzymes and effective and selective depolymerizers of agroforestry residues, and therefore their use would be beneficial in numerous environmentally friendly technologies.
\end{abstract}

Keywords: agroforestry residues, depolymerization selectivity, laccase, lignocellulose pretreatment, Mn-oxidizing peroxidases

\section{INTRODUCTION}

Increasing world population demands for intensive global agriculture production, which then leads to the release of millions of tons of residues every year. ${ }^{1}$ The majority of these residues remain unexploited, contributing to the problem of waste accumulation and environmental pollution. There are numerous reports demonstrating this fact. Thus, according to the data of the Food and Agricultural Organization (FAO), the global production of wheat in 2019 was 762.2 million tons, while as much as 529 million tons of wheat straw are produced annually. ${ }^{2}$ Likewise, considering the FAO database on the global production of apples $(83,000,398$ metric tons in 2017), or the production of blackberry in Serbia, a leading European producer $(27,558$ tons in 2013), an enormous amount of cuttings obtained after annual trimming is evident.

On the other hand, sustainable industries require a constant source of cost-effective raw materials and the application of green technology, without the use of any hazardous and energydemanding methods. ${ }^{3}$ Thus, the replacement of traditional chemical and physical lignocellulosic treatments with biological, i.e. enzymatic ones, could decrease the pressure of ecological issues. Nowadays, white-rot fungi are considered as effective producers of highly active and low substrate-specific ligninolytic enzymes that could meet the high demand for bio-safe catalysts in industrial processes, such as food, feed, biofuel and paper production, as well as for bioremediation. $^{4-6}$ However, even though ligninolytic enzyme complexes from white rots participate in a wide range of biotechnological processes, there are still many issues that need to be solved before their implementation at an industrial scale. Thus, the selection of the best enzyme producer(s), improvement of their productivity, and reduction of production costs are considered major priorities. ${ }^{7}$

Lignocellulose is composed of lignin, a polyphenolic and recalcitrant substance acting as a protective shield, two polysaccharides cellulose and hemicelluloses, as well as a small number of other components. ${ }^{8}$ Owing to the lignin structure and nature, enzymatic degradation of plant residues is very slow. Therefore, the implementation of lignocellulose in industrial 
processes requires its effective pretreatment, i.e. to remove the lignin as a prime barrier, making holocellulose more accessible for further hydrolysis. 9 The most operative enzymes associated with lignin degradation are lignin- and Mn-oxidizing peroxidases, laccases, and some auxiliary enzymes. ${ }^{11}$

Numerous previous studies indicate the significant potential of Pleurotus spp. for lignin degradation making them attractive biological agents for lignocellulosic bioconversion. ${ }^{6,12,13}$ For instance, Stajić et al. ${ }^{13}$ screened 31 strains of 10 Pleurotus species cultivated on two abundant agricultural residues and demonstrated their great ability to produce highly active ligninolytic enzymes, especially laccase and versatile peroxidase. Recently, Zou et al. ${ }^{14}$ also isolated and characterized one more novel versatile peroxidase from $P$. pulmonarius fruiting bodies stable at high temperature and extreme $\mathrm{pH}$, which could be applied in special industrial processes.

Based on the high capacity of Pleurotus species to synthesize active laccase and Mnoxidizing peroxidases during lignocellulose degradation, the objectives of this study were defined as follows: to characterize the ligninolytic enzymes of $P$. eryngii and $P$. pulmonarius produced after cultivation on five common agroforestry residues and determine their potential to selectively remove lignin, cellulose and hemicelluloses.

\section{EXPERIMENTAL}

\section{Organism and cultivation conditions}

The cultures of Pleurotus eryngii HAI 1017 and $P$. pulmonarius HAI 509 were obtained from the culture collection of the Institute of Evolution, University of Haifa (HAI) Israel, and maintained on malt agar medium at $4{ }^{\circ} \mathrm{C}$, in the culture collection of the Institute of Botany, Faculty of Biology, University of Belgrade.

According to the method of Stajic et al., ${ }^{15}$ the inoculum was prepared by (i) inoculation of $100 \mathrm{~mL}$ of synthetic medium (glucose, $10.0 \mathrm{~g} / \mathrm{L} ; \mathrm{NH}_{4} \mathrm{NO}_{3}, 2.0$ $\mathrm{g} / \mathrm{L} ; \mathrm{K}_{2} \mathrm{HPO}_{4}, 1.0 \mathrm{~g} / \mathrm{L} ; \mathrm{NaH}_{2} \mathrm{PO}_{4} \times \mathrm{H}_{2} \mathrm{O}, 0.4 \mathrm{~g} / \mathrm{L} ;$ $\mathrm{MgSO}_{4} \times 7 \mathrm{H}_{2} \mathrm{O}, 0.5 \mathrm{~g} / \mathrm{L}$; yeast extract, $2.0 \mathrm{~g} / \mathrm{L} ; \mathrm{pH}$ $6.5)$, with mycelial agar discs of 7-day old culture, (ii) incubation at room temperature $\left(22 \pm 2{ }^{\circ} \mathrm{C}\right)$ on a rotary shaker (100 rpm), (iii) washing of the obtained biomass with sterilized distilled water (three times) and (iv) homogenization in a laboratory blender. Solid-state cultivation was carried out at $25^{\circ} \mathrm{C}$, during 21 days, in $250 \mathrm{~mL}$-flasks containing $6.0 \mathrm{~g}$ of selected plant residues as carbon source (wheat straw, corn stalk, and apple, blackberry and oak sawdust) and $30.0 \mathrm{~mL}$ of the modified synthetic medium (without glucose) inoculated with $9.0 \mathrm{~mL}$ of the homogenized inoculums.

\section{Assays of enzyme activity and total protein production}

The ligninolytic enzymes were extracted by sample stirring with $50.0 \mathrm{~mL}$ of distilled water $\left(\mathrm{dH}_{2} \mathrm{O}\right)$ on a magnetic stirrer $\left(4{ }^{\circ} \mathrm{C}, 450 \mathrm{rpm}, 10 \mathrm{~min}\right)$. The obtained extracts were centrifuged $\left(4{ }^{\circ} \mathrm{C}, 3000 \mathrm{rpm}, 15 \mathrm{~min}\right)$, and the resulting supernatants were used for spectrophotometrical [CECIL CE2501 (BioQuest), $\mathrm{UK}$ ] measurement of Mn-oxidizing peroxidases [Mndependent peroxidase (MnP, EC 1.11.1.13), versatile peroxidase (VP, EC 1.11.1.16)] and laccase (EC 1.10.3.2) activity, as well as total proteins content. Mnoxidizing peroxidases activity was determined by monitoring the $\mathrm{A}_{610}$ change related to the rate of oxidation of phenol red $\left(\varepsilon_{610}=22000 \mathrm{M}^{-1} \mathrm{~cm}^{-1}\right)$ as a substrate, while 2,2'-azino-bis-[3-ethylthiazoline-6sulfonate] $(\mathrm{ABTS})\left(\varepsilon_{436}=29300 \mathrm{M}^{-1} \mathrm{~cm}^{-1}\right)$ was used as a substrate for defining laccase activity. ${ }^{15}$ The reaction mixture for the measurement of the peroxidases was composed of succinate buffer ( $\mathrm{pH} 4.5$ ), sample, 2.0 $\mathrm{mM} \mathrm{H}_{2} \mathrm{O}_{2}$, phenol red, and $2.0 \mathrm{mM} \mathrm{MnSO}$ for $\mathrm{MnP}$ or without it for VP. Reaction was stopped by the addition of $2 \mathrm{M} \mathrm{NaOH}$. The reaction mixture for determining the laccase activity consisted of phosphate buffer ( $\mathrm{pH}$ 6.0), ABTS and sample. Enzyme activity of $1 \mathrm{U}$ was defined as the amount of enzyme that transforms $1 \mu \mathrm{M}$ of substrate per minute.

\section{Electrophoresis}

Screening of the laccase profile of $P$. eryngii HAI 1017 and $P$. pulmonarius HAI 509 was performed after cultivation on all tested plant residues. A Mini IEF Cell-Model 111 (BIO-RAD) was used for isoelectric focusing (IEF) and defining the isoelectric points (pI) of enzyme isoforms. IEF was carried out on $7.5 \%$ polyacrylamide gel with $5.0 \%$ ampholytes in a $\mathrm{pH}$ gradient from 3.0 to 10.0 , using the IEF marker (pI values range from 3.6 to 9.3; Sigma-Aldrich). ABTS/phosphate buffer solution was used for dyeing the laccase bands. After focusing, the gel was fixed in $12.0 \%$ trichloroacetic acid and protein bands were detected by staining with $0.1 \%$ Coomassie Brilliant Blue R (CBB R) in fixative (methanol, acetic acid, and $\mathrm{H}_{2} \mathrm{O}$ in the ratio of $\left.45: 10: 45\right){ }^{16}$

\section{Determination of hemicelluloses, cellulose and lignin content}

The loss of substrate dry matter (\%) was determined by the formula $(\mathrm{M} i-\mathrm{M} f) / \mathrm{M} i \times 100$, where $\mathrm{M} i$ represents the initial lignocellulosic mass and $\mathrm{M} f$ is the mass after fermentation by the studied species.

The contents of hemicelluloses, cellulose and lignin were determined in untreated and fungal-treated selected agroforestry residues by the modified methods of Goering and Van Soest, ${ }^{17}$ Kirk and Obst ${ }^{18}$ and Van Soest et al. ${ }^{19}$ The plant residue was air-dried, ground to pass a 20 -mesh screen, and then dried in an oven at 50 
${ }^{\circ} \mathrm{C}$. The dried and finely ground samples were treated by neutral-detergent solution (NDS), boiled and refluxed. Acid-detergent solution (ADS) and 72\% $\mathrm{H}_{2} \mathrm{SO}_{4}$ were used for removing the hemicelluloses and cellulose from the residues for determining the lignin content (LC). The difference in weights of the samples treated with NDS and ADS represents the hemicellulose content, while the difference in the mass of the sample after the treatment with ADS and LC represents the cellulose content. The selectivity index, an indicator of selectivity in lignin degradation, was calculated as the ratio between removed lignin and cellulose.

\section{Statistical analyses}

All the experiments were done in three replicates and the results were expressed as mean \pm standard error. One-way analysis of variance (ANOVA) and Tukey's test were performed using STATISTICA version 6.0 (StatSoft, Inc., Tulsa, USA) to test any significant differences among means $(p<0.05)$.

\section{RESULTS AND DISCUSSION}

Pleurotus eryngii HAI 1017 and $P$. pulmonarius HAI 509 secreted the assayed enzymes during cultivation on all the tested plant residues, showing substrate-dependent activity, as well as interspecies diversity on each substrate (Fig. 1).

Corn stalks and wheat straw were favorable lignocellulosic residues for the production of highly active Mn-oxidizing peroxidases in both studied species. The peak of MnP activity was detected after corn stalks degradation by $P$. pulmonarius (2511.36 $\mathrm{U} \mathrm{L}^{-1}$ ), while this value was slightly lower in $P$. eryngii $\left(2417.93 \mathrm{U} \mathrm{L}^{-1}\right)$. Wheat straw was also a good substrate for $\mathrm{MnP}$ activity, while it was a few-fold lower after cultivation on other substrates, and even absent on blackberry sawdust. It was observed that, depending on the substrate type, VP activity in both species showed great variation, ranging between $18.55 \mathrm{U} \mathrm{L} \mathrm{L}^{-1}$ after apple sawdust degradation by $P$. eryngii and $3053.03 \mathrm{U} \mathrm{L}^{-1}$ on corn stalks degraded by $P$. pulmonarius. Wheat straw, as well as oak sawdust, also have enhanced VP synthesis, especially in $P$. pulmonarius (Fig. 1). The peak of laccase activity of $36052.33 \mathrm{U} \mathrm{L}^{-1}$ was observed after oak sawdust degradation by $P$. pulmonarius, apple sawdust was a more than twice weaker stimulator of the activity (16291.24 $\mathrm{U} \mathrm{L}^{-1}$ ), while the other tested substrates were worse inducers of the enzyme. Contrary to $\mathrm{Mn}$ oxidizing peroxidases, wheat straw did not favour the laccase synthesis in both species, while blackberry sawdust remarkably enhanced laccase synthesis in $P$. pulmonarius and almost repressed it in $P$. eryngii, causing the minimal activity of $300.30 \mathrm{U} \mathrm{L}^{-1}$ (Fig. 1).

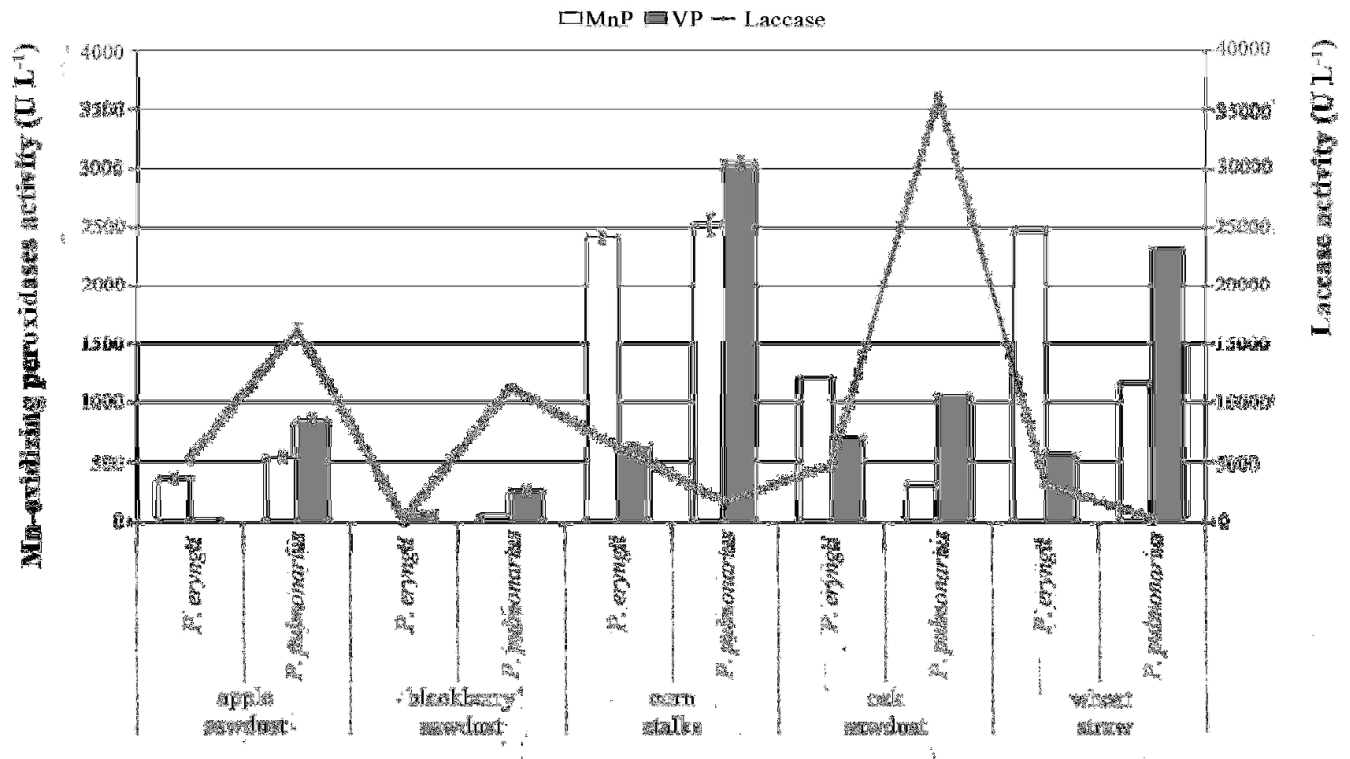

Studied species; agro-forestry residues

Figure 1: Activity of Mn-oxidizing peroxidases and laccases produced by Pleurotus eryngii HAI 1017 and $P$. pulmonarius HAI 509 after 21 days of solid-state cultivation on selected agroforestry residues 

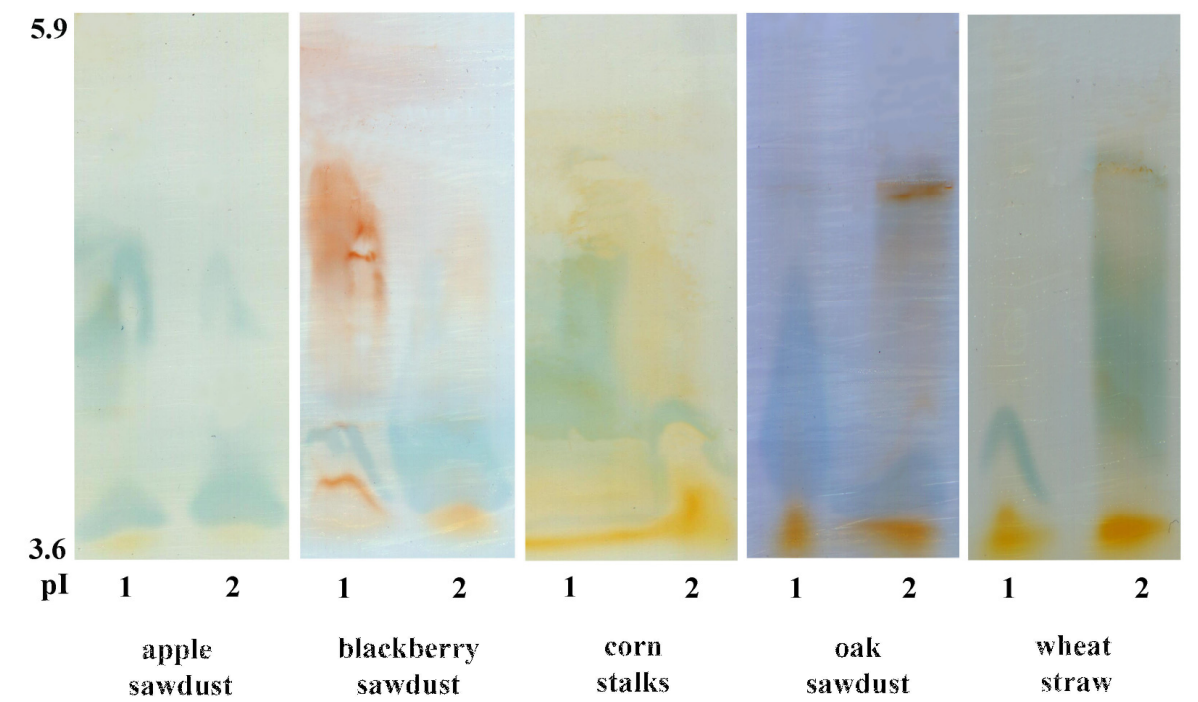

Figure 2: Profiles of laccase isoforms in Pleurotus eryngii HAI 1017 (1) and P. pulmonarius HAI 509 (2) after cultivation on selected agroforestry residues

Regarding the great activity of laccase synthesized by both Pleurotus species, its isoenzyme profiles were monitored. According to the zymogram, the number and intensity of bands were affected by the agroforestry residues and varied among the tested species as well (Fig. 2). Thus, the highest activity of laccase detected in $P$. pulmonarius on oak sawdust revealed several isoforms, with isoelectric points (pI) ranging from 3.6 to 5.1. Similarly, apple sawdust also initiated the production of several laccase isoforms of the same pI range in both species, which was in accordance with its significant activity. Moreover, the laccase zymogram showed that $P$. pulmonarius was dominant in the number of visualized isoforms on the tested lignocellulosics (Fig. 2).

The efficiency of the selected enzymes of the Pleurotus species was indicated by the extent to which the lignocellulosic polymers were degraded. Generally, the dry matter loss was affected by both substrate type and the tested species. Thus, the highest loss of dry mass (20.62\%) was observed in corn stalks fermented by $P$. pulmonarius. A similar capacity of total dry mass reduction of $19.52 \%$ and $19.86 \%$ was noted for blackberry sawdust and wheat straw, respectively, after cultivation of the same species (Table 1). The capacity of substrate delignification, as well as the selectivity in polymer degradation, also varied between the studied species (Table 1). The maximum of lignin loss was obtained in corn stalks $(46.3 \%)$ and slightly lower in wheat straw $(41.52 \%)$ fermented by $P$. pulmonarius.

However, to evaluate the efficiency of lignin loss, it was necessary to compare the selectivity indices. In most cases, a higher index was noted for $P$. pulmonarius than for $P$. eryngii, which indicated higher selectivity of the decomposition of selected substrates (Table 1). However, despite the best delignification, $P$. pulmonarius did not show the highest degradation selectivity, in contrast with $P$. eryngi, which possessed a significantly lower capacity of lignin removal from wheat straw $(19.12 \%)$, but the highest selectivity index (2.76). Nevertheless, remarkable lignin degradation, as well as selectivity (2.30) were recorded during wheat straw degradation by $P$. pulmonarius. The same species also showed high efficiency in hemicellulose depolymerization, especially in apple sawdust $(45.73 \%)$ and slightly lower in corn stalks $(43.16 \%)$. In terms of cellulose consumption, $P$. pulmonarius was also the best degrader, especially in corn stalks $(29.65 \%)$, in contrast with $P$. eryngii, which mineralized only $6.93 \%$ of wheat straw cellulose (Table 1). The main challenge in numerous biotechnological processes based on lignocellulose usage is efficient pretreatment, which means as much lignin loss as possible, while retaining the maximum holocellulose possible. 
Table 1

Depolymerization of selected agroforestry residues by Pleurotus eryngii and $P$. pulmonarius

\begin{tabular}{|c|c|c|c|c|c|c|c|c|c|c|}
\hline \multirow{2}{*}{$\begin{array}{l}\text { Agroforestry } \\
\text { residues }\end{array}$} & \multirow{2}{*}{$\begin{array}{l}\text { Studied } \\
\text { samples }\end{array}$} & \multirow{2}{*}{$\begin{array}{c}\text { Sample } \\
\text { weight }(\mathrm{g})\end{array}$} & \multicolumn{3}{|c|}{$\begin{array}{l}\text { Fibre composition } \\
\text { of samples (mg) }\end{array}$} & \multirow{2}{*}{$\begin{array}{c}\text { Dry matter } \\
\text { loss } \\
(\%)\end{array}$} & \multicolumn{3}{|c|}{$\begin{array}{c}\text { Extent of polymer } \\
\text { degradation }(\%)\end{array}$} & \multirow{2}{*}{$\begin{array}{l}\text { Selectivity } \\
\text { index }\end{array}$} \\
\hline & & & Lignin & Cellulose & Hemicelluloses & & Lignin & Cellulose & Hemicelluloses & \\
\hline \multirow{3}{*}{$\begin{array}{l}\text { Apple } \\
\text { sawdust }\end{array}$} & Control* & 6.00 & 1158.00 & 2808.00 & 1176.00 & l & I & I & / & I \\
\hline & P. eryngii & 5.30 & 970.08 & 2237.02 & 1107.19 & $11.65^{\mathrm{b}}$ & $25.54^{\mathrm{c}}$ & $26.27^{\mathrm{d}}$ & $10.88^{\mathrm{a}}$ & $0.97^{\mathrm{a}}$ \\
\hline & P. pulmonarius & 5.02 & 999.18 & 2289.58 & 873.65 & $15.96^{\mathrm{d}}$ & $9.86^{\mathrm{a}}$ & $18.43^{\mathrm{c}}$ & $45.73^{\mathrm{d}}$ & $0.53^{\mathrm{a}}$ \\
\hline \multirow{3}{*}{$\begin{array}{l}\text { Blackberry } \\
\text { sawdust }\end{array}$} & Control* & 6.00 & 1218.00 & 2712.00 & 1038.00 & l & / & l & / & l \\
\hline & P. eryngii & 5.08 & 827.55 & 2005.42 & 883.40 & $15.42^{\mathrm{d}}$ & $32.06^{\mathrm{d}}$ & $26.05^{\mathrm{d}}$ & $14.89^{\mathrm{a}}$ & $1.23^{\mathrm{b}}$ \\
\hline & P. pulmonarius & 4.83 & 907.85 & 2173.05 & 709.86 & $19.52^{\mathrm{e}}$ & $25.46^{\mathrm{c}}$ & $19.87^{\mathrm{c}}$ & $31.61^{\mathrm{c}}$ & $1.28^{\mathrm{b}}$ \\
\hline \multirow{3}{*}{$\begin{array}{l}\text { Corn } \\
\text { stalks }\end{array}$} & Control* & 6.00 & 594.00 & 2796.00 & 1860.00 & / & l & I & / & I \\
\hline & P. eryngii & 5.18 & 522.88 & 2350.36 & 1242.48 & $13.72^{\mathrm{c}}$ & $11.97^{\mathrm{a}}$ & $15.94^{\mathrm{c}}$ & $33.22^{\mathrm{c}}$ & $0.75^{\mathrm{a}}$ \\
\hline & P. pulmonarius & 4.76 & 319.12 & 1967.12 & 1057.39 & $20.62^{\mathrm{e}}$ & $46.28^{\mathrm{e}}$ & $29.65^{\mathrm{e}}$ & $43.16^{\mathrm{d}}$ & $1.56^{\mathrm{b}}$ \\
\hline \multirow{3}{*}{$\begin{array}{l}\text { Oak } \\
\text { sawdust }\end{array}$} & Control* & 6.00 & 1530.00 & 2808.00 & 1159.00 & / & I & I & / & I \\
\hline & P. eryngii & 5.51 & 1157.73 & 2469.82 & 1102.60 & $8.12^{\mathrm{a}}$ & $24.33^{\mathrm{c}}$ & $12.07^{\mathrm{b}}$ & $17.99^{\mathrm{b}}$ & $2.01^{\mathrm{c}}$ \\
\hline & P. pulmonarius & 5.20 & 1133.16 & 2474.25 & 951.23 & $13.36^{\mathrm{c}}$ & $25.94^{\mathrm{c}}$ & $11.91^{\mathrm{b}}$ & $17.99^{\mathrm{b}}$ & $2.18^{\mathrm{c}}$ \\
\hline \multirow{3}{*}{$\begin{array}{l}\text { Wheat } \\
\text { straw }\end{array}$} & Control* & 6.00 & 666.00 & 2418.00 & 1692.00 & / & l & I & / & I \\
\hline & P. eryngii & 5.33 & 538.63 & 2250.53 & 1359.92 & $11.12^{\mathrm{b}}$ & $19.12^{\mathrm{d}}$ & $6.93^{\mathrm{a}}$ & $19.63^{\mathrm{b}}$ & $2.76^{\mathrm{c}}$ \\
\hline & P. pulmonarius & 4.81 & 389.45 & 1980.90 & 1096.22 & $19.86^{\mathrm{e}}$ & $41.52^{\mathrm{e}}$ & $18.08^{\mathrm{c}}$ & $35.21^{\mathrm{c}}$ & $2.30^{\mathrm{c}}$ \\
\hline
\end{tabular}

*uninoculated plant residue

*values superscripted with the same letter in the same column are not significantly different $(p<0.05)$ 
Despite to existence of efficient physicochemical delignification processes, currently, special attention is given to biological ones, owing to their unhazardous nature. Numerous studies have demonstrated a very operative mushroom ligninolytic system, especially in species of the genus Pleurotus, which could be environmentally friendly alternatives to existing delignification methods. ${ }^{20}$ Similarly to the results obtained in this study, many previous reports demonstrated significant interand intraspecies variability in the activity of ligninolytic enzymes among Pleurotus species, which significantly depended on the type and composition of the lignocellulose substrate..$^{10,21,22,23}$ However, the majority of the lignocellulose residues in our study were tested for the first time, which made it impossible to compare the results obtained in this work with others reported in the literature. Still, Dong et $a l .^{21}$ demonstrated extremely high activity of $\mathrm{MnP}$ synthesized by $P$. ostreatus on sugarcane bagasse $\left(150,000 \mathrm{U} \mathrm{L}^{-1}\right)$, comparing with the maximum value obtained in our study. On the contrary, Wayman et al. ${ }^{22}$ reported that corn stover was a significantly weaker inducer of $\mathrm{MnP}$ synthesis in P. eryngii and P. ostreatus. Similarly, the dependence of laccase activity on the substrate type was also previously demonstrated. Thus, Bettin et al. ${ }^{24}$ showed that fructose and glucose as carbon sources stimulated the secretion of highly active laccase isoforms in P. sajor-caju $\left(37,000 \mathrm{U} \mathrm{L}^{-1}\right.$ and $36,000 \mathrm{U} \mathrm{L}^{-1}$, respectively). Sugarcane bagasse was also a good enhancer of laccase activity in P. ostreatus, causing similar activity as oak sawdust did in P. pulmonarius HAI 509 $\left(\sim 35,000 \mathrm{U} \mathrm{L}^{-1}\right)$, but after a twice longer period of cultivation. ${ }^{21}$ On the other hand, orange waste has not favored laccase production in $P$. pulmonarius and $P$. ostreatus, whose activity was only about $10000 \mathrm{U} \mathrm{L}^{-1} \cdot{ }^{25}$ However, in comparison with other white rots, Pleurotus spp. are superior producers of this enzyme. This could be demonstrated by the results of Ćilerdžić et al. ${ }^{16}$ and Mikiashvili et al. ${ }^{26}$ who showed that Ganoderma applanatum and Grifola frondosa synthesized low active laccase isoforms during oak sawdust degradation $\left(10,000 \mathrm{U} \mathrm{L}^{-1}\right.$ and $703.3 \mathrm{U} \mathrm{L}^{-1}$, respectively).

Inter- and intraspecies genetic variability, as well as the substrate nature, also affected the laccase isoenzyme profile within the genus Pleurotus. ${ }^{10,27}$ Namely, during solid-state cultivation on wheat straw, $P$. eryngii synthesized two laccase isoforms ( $\mathrm{pI}$ of 3.6 and 4.6), while only one band was visualized for $P$. pulmonarius. ${ }^{10}$ However, Marques de Souza and Peralta ${ }^{27}$ observed at least two laccase isoforms in $P$. pulmonarius after solid-state cultivation on a wheat bran-based substrate. The capacity of the expressed enzymes of the studied Pleurotus species to delignify selected plant residues was remarkable and also depended on the lignocellulose substrate. In the comparison with previous results, $P$. eryngii HAI 1017 and P. pulmonarius HAI 509 were more efficient removers of lignin from wheat straw than Pleurotus species and strains studied by Salmones et al. ${ }^{28}$ and Knežević et $a l .{ }^{29}$ but slightly weaker than the strains tested by Ćilerdžić et al. ${ }^{10}$ The strain of $P$. eryngii, whose ligninolytic enzymes were profiled by Asgher et al., ${ }^{30}$ caused up to $48.05 \%$ and $49.52 \%$ lignin loss from corn cobs and corn stover, respectively, which was about four-fold higher than the extent of corn stalk delignification by $P$. eryngii HAI 1017 $(11.97 \%)$. The capacity of the studied species to mineralize blackberry and apple sawdust was determined for the first time. Generally, the tested species significantly differed in the extent of lignin removal from wheat straw and corn stalks, as grasses, and the tested sawdust, which could be explained by differences in the lignin/holocellulose ratio, as well as the lignin and cell wall structure of the substrates. ${ }^{31}$

Considering the ranking proposed by Liers et al. ${ }^{32}$ according to which species with a selectivity index for lignocellulose depolymerization between 1.0 and 1.9 represent highly effective delignifiers, it can be concluded that $P$. eryngii HAI 1017 and $P$. pulmonarius HAI 509 are extremely selective depolymerizers of wheat straw and oak sawdust, with indices $>2.0$.

\section{CONCLUSION}

Several key conclusions can be drawn from this study: (i) Pleurotus eryngii HAI 1017 and $P$. pulmonarius HAI 509 have been revealed as effective and selective depolymerizers of highly available agricultural and forestry residues; (ii) apple and blackberry sawdust, agricultural wastes investigated for the first time in this work, could be good raw materials for some biotechnological applications, owing to the fact that they are susceptible to the action of Pleurotus spp. Enzymes, which 
selectively mineralized them; (iii) $P$. eryngii HAI 1017 and P. pulmonarius HAI 509, as good producers of ligninolytic enzymes and effective delignifiers, can be considered as the main participants in numerous novel environmentally friendly technologies, which should be more competitive, compared with conventional ones; (iv) the obtained results represent the basis for future studies aiming to optimize the production of the enzymes on an industrial scale.

ACKNOWLEDGEMENTS: This study was financially supported by the Ministry of Education, Science and Technological Development of the Republic of Serbia (45103-68/2020-14/200178). The authors are especially grateful to the farms Žerađanin (from Vrnjačka Banja) and Nikolić (from Obrenovac) that provided the agricultural wastes and thus contributed to the experiment.

\section{REFERENCES}

1 A. Shikata, J. Sermsathanaswadi, T. Thianheng Phakhinee, S. Baramee, C. Tachaapaikoon et al., Enzyme Microb. Tech., 118, 66 (2018), https://doi.org/10.1016/j.enzmictec.2018.07.001

2 S. P. Govumoni, S. Koti, S. Y. Kothagouni, S. Venkateshwar and V. R. Linga, Carbohyd. Polym., 91, 646 https://doi.org/10.1016/j.carbpol.2012.08.019

3 S. H. Ghaffar, M. Fan and B. McVicar, Ind. Crop. Prod., 77, $262 \quad$ (2015), http://dx.doi.org/10.1016/j.indcrop.2015.08.060

4 L. Gudynaite-Savitch and T. C. White, in "Gene Expression Systems in Fungi: Advancements and Applications", edited by M. Schmoll and C. Dattenböck, Springer International Publishing, 2016, pp. 395-439

M. Stajić, J. Vukojević, I. Milovanović, J. Ćilerdžić and A. Knežević, in "Biomass Conversion. Microbial Enzymes in Bioconversions of Biomass", edited by V. K. Gupta, Springer International Publishing, 2016, pp. 251-269

6 A. S. Sekan, O. S. Myronycheva, O. Karlsson, A. P. Gryganskyi and Y. Blume, Peer J., (2019), https://doi.org/10.7717/peerj.6664

K. Ikehata, I. D. Buchanan and D. W. Smith, J. Environ. Eng. Sci., 3, 1 (2004), https://doi.org/10.1139/s03-077

8 M. Adsul, S. Kaur, S. Reeta, R. Singhania et al., Enzyme Microb. Tech., 133, 109442 (2020), https://doi.org/10.1016/j.enzmictec.2019.109442

9 S. I. Mussatto, E. M. Machado, L. M. Carneiro and J. A. Teixeira, Appl. Energ., 92, 763 (2012), https://doi.org/10.1016/j.apenergy.2011.08.020

10 J. Ćilerdžić, M. Galić, J. Vukojević, I. Brčeski and M. Stajić, BMC Plant Biol., 17, 75 (2017), http://dx.doi.org/10.1186/s12870-017-1196-y

11 G. Janusz, K. H. Kucharzyk, A. Pawlik, M. Staszczak, A. J. Paszczynski et al., Enzyme Microb. Tech., 52, 1 (2013), https://doi.org/10.1016/j.enzmictec.2012.10.003

12 J. Poppe, Mushroom Sci., 15, 3 (2000), http://hdl.handle.net/1854/LU-400814

13 M. Stajić, L. Persky, E. Cohen, Z. Hadar, I. Brčeski et al., Appl. Biochem. Biotech., 117, 155 (2004), https://doi.org/10.1385/abab:117:3:155

14 Y. J. Zou, H. X. Wang and J. X. Zhang, Int. J. Pept. Res. Ther., 25, 1389 (2019), https://link.springer.com/article/10.1007/s10989-

018-9784-8

15 M. Stajić, B. Kukavica, J. Vukojević, J. Simonić, S. Veljović-Jovanović et al., BioResources, 5, 2362 (2010)

16 J. Ćilerdžić, M. Stajić and J. Vukojević, Int. Biodeter. Biodegr., 114, 39 (2016), https://doi.org/10.1016/j.ibiod.2016.05.024

17 H. K. Goering and P. J. Van Soest, Forage Fiber Analysis (Apparatus, Reagents, Procedures, and some Applications (No. 379). Agricultural Research Service, US Department of Agriculture (1970)

18 T. K. Kirk and J. R. Obst, in "Methods in Enzymology", edited by S. P. Colowick and N. O. Kaplan, AcademicPressInc., 1988, pp. 87-101

19 P. V. Van Soest, J. B. Robertson and B. A. Lewis, J. Dairy Sci., 74, 3583 (1991), https://doi.org/10.3168/jds.S0022-0302(91)78551-2 20 E. A. Adebayo and D. Martinez-Carrera, Afr. $J$. Biotechnol., $\quad \mathbf{1 4}, \quad 52 \quad$ (2015), http://dx.doi.org/10.5897/AJB2014.14249

${ }^{21}$ X. Q. Dong, J. S. Yang, N. Zhu, E. T. Wang and H. L. Yuan, Bioresour. Technol., 131, 443 (2013), https://doi.org/10.1016/j.biortech.2012.12.182

${ }_{22}$ V. Wayman, J. Henríquez, C. Palma and A. Carvajal, Bioresour. Technol., 247, 402 (2018), https://doi.org/10.1016/j.biortech.2017.09.055

${ }^{23}$ M. Stajić, L. Persky, D. Friesem, Y. Hadar, S. P. Wasser et al., Enzyme Microb. Tech., 38, 65 (2006), https://doi.org/10.1016/j.enzmictec.2005.03.026

24 F. Bettin, Q. Montanari, R. Calloni, T. A. Gaio, M. M. Silveira et al., J. Ind. Microb. Biotech., 36, 1 (2009), https://doi.org/10.1007/s10295-008-0463-1

25 E. N. de Freitas, G. A. Bubna, T. Brugnari, C. G. Kato, M. Nolli et al., Chem. Eng. J., 330, 1361 (2017), http://dx.doi.org/10.1016/j.cej.2017.08.051

26 N. A. Mikiashvili, O. S. Isikhuemhen and E. I. Ohimain, Braz. J. Microbiol., 42, 1101 (2011), https://dx.doi.org/10.1590\%2FS1517-

838220110003000031

27 C. G. Marques de Souza and R. M. Peralta, J. Basic Microb., 43, $278 \quad$ (2003), https://doi.org/10.1002/jobm.200390031

28 D. Salmones, G. Mata and K. N. Waliszewski, Bioresour. Technol., 96, $537 \quad$ (2005), https://doi.org/10.1016/j.biortech.2004.06.019

29 A. Knežević, I. Milovanović, M. Stajić, N. 
MILICA GALIĆ et al.

Lončar, I. Brčeski et al., Bioresour. Technol., 138,

117

https://doi.org/10.1016/j.biortech.2013.03.182

30 M. Asgher, S. W. Khan and M. Bilal, Rom.

Biotech. Lett., 21, 11133 (2016), https://erepository.org/rbl/vol.21/iss.1/7.pdf
31 M. Li, C. Foster, S. Kelkar, Y. Pu, D. Holmes et al., Biotechnol. Biofuels., 5, 38 (2012), https://doi.org/10.1186/1754-6834-5-38

32 C. Liers, T. Arnstadt, R. Ullrich and $M$. Hofrichter, FEMS Microbiol. Ecol., 78, 91 (2011), https://doi.org/10.1111/j.1574-6941.2011.01144.x 